\title{
THE DOE-RAY CORRESPONDENCE: A PIONEER COLLABORATION IN THE JURISPRUDENCE OF MENTAL DISEASE*
}

\author{
LOUIS E. REIK'ं
}

\begin{abstract}
"An ideal system of law should draw its postulates and its legislative justification from science. As it is now, we rely upon tradition, or vague sentiment, or the fact that we never thought of any other way of doing things, as our only warrant for rules which we enforce with as much confidence as if they embodied revealed wisdom." Holmes, Collected Legal Papers 138 (1920).
\end{abstract}

THE 19th century correspondence between Charles Doe of the New Hampshire Supreme Court ${ }^{1}$ and Isaac Ray, a pioneer American psychiatrist, has been recently compiled. Initiated by Judge Doe in 1866, the correspondence gives the intimate history of how he induced the New Hampshire Supreme Court to accept the view that, since insanity is a disease, "what is a diseased condition of mind is to be settled by science and not by law.". The resulting rule of law, established in State $v . P i k c^{3}$ and subsequently known as the "New Hampshire rule," has been proposed from time to time for wider adoption both in this country and in England. Currently, the forensic committee of the Group for the Advancement of Psychiatry, assisted by leading members of the legal profession, is advising abandonment of the $M I^{\prime}$ Naghten rules, which have dominated Anglo-American jurisprudence of mental diseases since 1843 . The committee's preliminary report proposes "following fairly closely to the line laid down in the New Hampshire case over eighty years ago."."

*The Doe-Ray correspondence, consisting of about two dozen letters, is in the Isaac Ray Medical Library at Butler Hospital, Providence. Doe's letters vere preserved among the papers of Isaac Ray, who was the first superintendent of the hospital. Recently, Miss Catherine Doe, daughter of Judge Doe, has generously donated to the library the letters of Isaac Ray to her father and has joined Dr. Henry H. Babcock, superintendent of Butler Hospital, in kindly granting permission for the publication of this correspondence.

$\doteqdot$ Psychiatrist, Health Department of Princeton University.

1. See Note, Doe of New Hampshire: Reflections on a Ninetcenth Coutury Judge, 63 Harv. L. REv. 513 (1950).

2. Letter from Judge Doe to Dr. Tyler, Sept. 5, 1866. See p. 187 infra.

3. 49 N.H. 399 (1869).

4. Gutmacher \& Wethofen, Psychlatky and the LAW 421 (1952). In 1923, a committee of the Medico-Psychological Association of Great Britain and Ireland suggested to the Committee on Insanity and Crime appointed by the Lord High Chancellor that "the responsibility of a prisoner should be left as a question of fact to be determined by the jury on the merits of the particular case." This is essentially the New Hampshire rule. Glueck, Mientai Disoroer and the Criminal Law 458 (1925). Some years ago, a com- 
The M'Naghten rules are the product of fifteen judges of the King's Bench in response to an appeal for clarification of the law and general enlightenment on legal responsibility and insanity. "The portion of the $M^{\prime}$ Naghten rules which has current relevance states: "[T]o establish a defence on the ground of insanity, it must be clearly proved that, at the time of the committing of the act, the party accused was labouring under such a defect of reason, from disease of the mind, as not to know the nature and quality of the act he was doing, or, if he did know it, that he did not know he was doing what was wrong." This statement "furnished the raw material for the various forms of the right-and-wrong test in America," a test which is apparently accepted everywhere but New Hampshire. ${ }^{8}$

Isaac Ray rejected the intellectualistic criteria set up by the M'Naghten judges because "responsibility implies the integrity of all the mental powers, moral as well as intellectual." A contemporary squarely stated the dilemma of those who regard knowledge per se as the true test: "How can we speak of intact judgment and reason [in the face of phenomena which] dethrone reason, and paralyze the operation of judgment?"10 Since Ray's time, medical psychology has abundantly supported the observation that the mind cannot be split up into isolated entities and has stressed the intimate interdependence of the psychological forces involved in knowing, willing, and feeling. ${ }^{11}$ Ray held that the question of legal responsibility is so complex that it is a "fundamental error" of the courts to attempt a solution through the use of general formulas without the aid of scientific research and consultation. ${ }^{12}$ Ray advocated two important principles: (1) the external manifestations of mental disease are so inconstant and uncertain that no legal definition or test of universal application is possible; (2) there is a form of mental illness in which behavior is so disordered and can be so detrimental either to the

mittee of distinguished lawyers and physicians of the American Institute of Criminal Law and Criminology drafted a "Criminal Responsibility Bill," $\$ 1$ of which resembles the New Hampshire rule. White, Insanity and the Criminal Law 141 et seq. (1923).

5. See Hall, Principles of Criminal Law 479 et seq. (1947).

6. 10 CL. \& F. 200, 210, 8 Eng. Rep. 718, 722 (1843).

7. GLUECK, op. cit. supra note 4 , at 215 .

8. In England and in 29 American states it is the sole test of irresponsibility. In 17 states and in the District of Columbia, the "irresistible impulse test" has been used in addition to the right-and-wrong test. WEIHOFEN, INSANTTY AS A DEFENSE IN CRIMiNal LAW 15-16 (1933).

9. Ray, Responsibility of the Insane for their Criminal Acts in Transactions of THE International Medical Congress 7 (1876).

10. Winslow, Lettsomian Lectures: On Medico-Legal Evidence in Cases of INSANITY 116 (1854).

11. Henderson \& Gillespie, A Text-Book of Psychiatry 707 (1950). See also, Meyer, The Rise to the Person and the Concept of Wholes or Integrates, in 3 Tne CoLLECTEd PAPERs of Adolf Meyer 492 et seq. (1951) ; Zilboorg \& Henry, A History of MediCAL PsychologX 479 et seq. (1941).

12. Ray, A Treatise on the Medical Jurisprudence of Insanity 62 (5th ed. 1871). 
patient or to others, or to both, that, in spite of seemingly intact intellectual ability and the absence of delusion, the patient seems to be the victim of emotional or "moral" forces beyond his control. ${ }^{13}$ American psychiatry has generally followed Ray's lead. ${ }^{14}$

The New Hampshire rule similarly recognized that there is no general definition or criterion for responsibility in mental disease which would have universal application. Judge Doe refused to grant judicial sanction to controversial medico-legal tests and definitions. Instead, the procedure adopted was in essence to tell the jury that mental illness defies definition, that no tests are applicable to every case, and that the jury must judge the case on its individual merits. If the jury believed from the evidence, expert and otherwise, that the act in question was the result of mental disease, the verdict must be "not guilty" because of insanity. ${ }^{15}$

While granting that Ray's principles were valid, Judge Doe avoided basing his arguments on Ray's medical authority because he feared that the arguments would be summarily dismissed by the legal profession as merely "doctor's notions."16 Instead, he based them squarely on legal grounds: the common law recognizes insanity as a disease that cannot produce contracts or crimes, and the common law does not distinguish "only a certain lind or degree of insanity as having any legal consequences." ${ }^{17}$ Although Doe was anxious to give recognition to Ray's personal labors, he did not wish to appear to be arguing for a new medical theory. He proceeded, instead, on the assumption that his fellow-judges and the legal profession as a whole would be more easily convinced if he confined his arguments to purely legal grounds. Similarly, Doe did not wish to appear as the personal champion of the reform which he proposed. Once his fellow-judges had been convinced, Judge Doe insisted that they appear as the leading spirits in the reform. ${ }^{18}$

13. Id. at $324,327$.

14. Zilboorg, Legal Aspects of Psychiatry in One Hunden Yeurs of Azsmenii Psychiatry 583 (1941).

15. In State v. Pike, 49 N.H. 399 (1869), the New Hampshire rule was applied for the first time. The judge instructed the jury "that the verdict should be, Not guilty by reason of insanity' if the killing vas the offspring or product of mental disease in the defendant; that neither delusion nor knowledge of right and wrong, nor design or cunning in planning and executing the hilling and escaping or avoiding detection, nor ability to recognize acquaintances, or to labor or transact business or manage afiairs is, as a matter of law, a test of disease; but that all symptoms and all tests of mental disease are purely matters of fact to be determined by the jury." Id. at 702 .

16. Letter from Judge Doe to Dr. Ray, Mar. 23, 1869. See p. 194 infro.

17. Letter from Judge Doe to Dr. Ray, May 18, 180s. See p. 189 infra.

18. Judge Doe's "peers must certainly be sought among those few who have profoundly revolutionized existing ideas of common law administration and of the law of evidence, who have guided us by historical researches to the birth of legal conceptions and have skillfully separated legal truth from the matrix of circumstance. In all the array of judges who have administered the common law none can be found who has so clearly pointed out the judicial duty of subordinating legal machinery to legal rights." Hening, Eight Great Averican Lawyers 241, 316 (1909). 
The Doe-Ray correspondence, therefore, has current interest as well as historical value to students of the legal aspects of mental disease. Not only does it show how the New Hampshire rule evolved, but it also contains the mature thought and conclusions of two brilliant men, each deeply interested in effecting closer harmony between science and the law, and each anxious to end the controversy between doctors and lawyers over the law of insanity. Moreover, one of the chief points of fascination in this correspondence lies in its description of how Judge Doe succeeded in bringing about his colleagues' acceptance of the New Hampshire rule.

\section{The CorRespondence}

The major theme of the correspondence and Judge Doe's chief reason for proposing the New Hampshire rule is his conclusion that the "great masters of our law" never made the distinction between law and fact in cases of insanity. By setting up various theoretical criteria for legal responsibility, they not only invaded the realm of science, but also betrayed the spirit of the common law. He found, in short, that they made the great mistake, for reasons of expediency, of instructing juries in matters of science and fact.

Among the letters written by Judge Doe in the Ray collection are two addressed to Dr. John E. Tyler, Professor of Mental Diseases at Harvard Medical School. Lacking any personal acquaintance with Ray, Doe was consulting Tyler in connection with the dissenting opinion he was preparing in the case of Boardman v. Woodman. ${ }^{10}$ These two opening letters show that Judge Doe, at the age of thirty-six, had already reached the conclusion which later he became instrumental in having adopted by the Supreme Court of his state. His first letter to Tyler, dated February 10,1866, reads in part:

"Enclosed is a case of which I spoke to you at Haverhill last fall. ... When the decision of the other judges is published in our Reports, I design adding my own feeble dissenting opinion. But I wish to be sure that I am right. It will be a reproach to our law if it is found to be inconsistent with the principles universally accepted by scientific men.... The law on this subject has hitherto slowly advanced, following science considerably in the rear. . . . And even a dissenting opinion of myself will be valuable, if it states that to be law which is in fact true. ... I have too much pride of profession to allow it to be declared without protest that the law applies certain absolute tests on the question of sanity which your profession does not apply or does not regard as necessary or correct. . . .

"Dr. Ray, according to his work on the Medical Jurisprudence of Insanity, is not satisfied with the legal decisions ancient or modern. If I were acquainted with him I would send him a copy of this case

19. 47 N.H. 120 (1865). This was a testamentary case, in which Judge Doe attacked the traditional legal tests of insanity on the grounds that they were conceived and born in medical theory, and that "medical errors of former days gained the sanction and the name of law, by being published in law books of high authority." Id. at 148. 
and ask his views. Of course, his views and yours are the same. I should apply to him by way of acknowledgeing the debt due to him from my profession for his treatise which is doing very much to liberalise the minds of law students on this subject. If you should think the matter of sufficient consequence to consult with him or any one else, I will send you another copy of the case. . .."

Evidently, through Tyler's good offices, Judge Doe obtained an expression of opinion from Ray, for Doe wrote to Tyler again on September 5, 1866:

"Enclosed is Dr. Ray's letter, returned according to your request. I have taken a copy of it. Both his letter and yours are just what I wanted, and I shall try to put the substance of them into our Reports as an expression of what I understand to be the received medical opinion of this age, and I am greatly obliged both to you and Dr. Ray.

"It is common for my profession as well as yours to ridicule the notions of insanity entertained by Coke and Hale. But is it certain that Coke and Hale were behind their age? Did the great doctors of those days have more correct opinions on this subject than the great lawyers and judges? Were there any asylums for the insane in those days? Did any physician or other person then make it a lifebusiness to study and treat insanity? Was insanity then considered by the doctors to be a physical disease or the result of physical disease?... One more question: Is it now the settled opinion of the scientific world that insanity is only physical disease, or the result of physical disease? If you answer yes, why should the court ever say to a jury more than this in cases of alleged mental aberration or active insanity: 'If the disposition of property was the offspring of or was caused, or affected, by mental disease, then it is not the will of the testator,- - the result of disease can not have any effect in law.' Whether this will was caused, or affected, by disease is a question of fact to be determined by the jury and not by the court. The law does not define disease,- - disease is so simple an expression that the law need go no further. What is a diseased condition of mind is to be settled by science and not by law,-disease is wholly within the realm of natural law or the law of nature. The municipal, civil law established by men for human government does not declare what is disease of the mind any more than it declares what is disease of the lungs or liver. It is as proper for experts to testify that a man whom they have examined has or had cerebral or mental disease, as that he had consumption or rheumatism.

"Why should not that be correct and amply sufficient, saving in future all collision between law and science? Why should the law say that delusion is a test of any form of mental disease, when the law will not say that certain other symptoms are the tests of gout or fever or smallpox?... Why should the law undertake to know more about one disease than another? Why should a judge pretend to know that delusion is a test of anything unless he will also assume to have all medical knowledge and to hold, as matter of law, what are the tests of every kind of disease? ... I am strongly inclined to put it in the book that mental disease invalidates a will which was affected by the disease,- - that whether there was mental disease is for the 
jury to decide upon the evidence as to testator's condition and circumstances, and the testimony of experts as to what disease is-what amounts to disease-and that the court can never have any occasion to say anything about delusion. ..."20

The first surviving letter to Dr. Ray in this correspondence is dated almost two years later, April 14,1868, and encloses Doe's dissenting opinion in Boardman v. Woodman:

". . Being entirely convinced that you are right in your science, my only question was how your views should be applied to trials before court and jury, and the enclosed is the result to which I was driven, and from which I do not see how any lawyer can escape.

"Probably because you are not a mere lawyer, it did not occur to you that the tests of disease are questions of fact for a jury. Our law-books having treated tests of insanity as questions of law, it would have been strange if you had seen that that was a great mistake and the cause of the whole trouble. Whether the question of test will be safer in the hands of the jury or not, I am satisfied that it is a question of fact which, under our Constitution, cannot be taken from the jury. In this respect, the theory of the British Constitution is like ours, - questions of fact are for the jury.

"Giving this matter to the jury leaves the way open for the reception of all progress in your science. One jury is not bound by the verdict of another jury on a general question of fact or science, as courts sometimes feel themselves bound by decisions on general questions of law. My result takes off the shackles of precedent and authority, -opens the subject to be decided in each case as an entirely new subject. Juries may make mistakes, but they cannot do worse than courts have done in this business. ..."

Ray's reply, dated May 3, 1868, expresses doubtful reserve concerning Judge Doe's position. He points out that, in addition to the question of disease, the law is concerned with the problem of legal responsibility:

"... I am rejoiced that you have had the boldness, though singlehanded, to place the question of insanity where it rightfully belongs, - with the jury as a question of fact. ... I am not sure that I catch exactly the issue you make with the courts. That the tests which they have adopted are irrelevant, and therefore they are bound to suffer all the responsibility incurred by giving wrong instructions to the jury, is obvious enough; but, inasmuch as the law recognized

20. What Judge Doe has to say in this letter about insanity as disease is reminiscent of the following passage in Ray's A Treatise on THE Medichl JuRisprudence of INSANITY 39 (5th ed. 1871), appearing in the first as well as in subsequent editions: "Insanity is a disease, and, as is the case with all other diseases, the fact of its existence is never established by a single diagnostic symptom, but by the whole borly of symptoms, no particular one of which is present in every case. To distinguish the manifestations of health from those of disease, requires the exercise of special learning and judgment; and, if no one doubts this proposition, when stated in reference to the bowels, the lungs, the heart, the liver, the kidney, etc., what sufficient or even plausible reason is there, why it should be doubted when predicated of the brain?" 
only a certain kind or degree of insanity as having any legal consequences, how could the courts avoid the duty of defining by tests and rules what that kind or degree is? Had it been the law that insanity, without stint or qualification, should exempt from the ordinary legal consequences, then the courts would have had no concern with tests, and would have given the question to the jury as purely one of fact. If your meaning is that they should have taken this construction of the law, I can only say that this is what I have always maintained. Still, mistaken though they have been, did they go out of their province in saying that a certain form only of insanity annulled responsibility? And if justified in this, did it not become incumbent on them to define that form of disease by suitable tests?... If, then, insanity may or may not disqualify, must not this fact be recognized, in some way, by the statute? In the absence of any such recognition, what would be the practical effect in a contested will case? The court tells the jury that insanity necessarily annuls testament capacity. The existence of the disease is admitted by both sides, but counsel cite a host of cases in which the will was established in spite of admitted insanity. ..."

While Judge Doe's reply of May 18, 1868 , answers the point raised by Ray, he omits any consideration of the practical difficulties, which juries must face in deciding what is mental disease and what are the limitations of expert testimony. ${ }^{21}$

“.. I think the common law is as follows: it does not recognize 'only a certain kind or degree of insanity as having any legal consequences'; it recognizes insanity as disease, and, so far as contracts and crimes are governed by the common law, they cannot be produced by disease of the mind. Whether, in any particular case there is mental disease, and, if there is, whether a certain transaction is a product of that disease,-are questions of fact for the jury and not of law for the court. The court can only instruct the jury that a product or an offspring of mental disease is not a contract or a crime. I think the entire common law is stated above. ...

"In early times (and to this day in England and some of our states), the courts charged juries upon many matters of fact,- disregarding the distinction between law and fact, a practice which readily accounts for much, if not all, of the confusion that now prevails in the law of insanity. Lord Hale, being accustomed to charge juries according to the medical opinions of that day, and to hear

21. Critics of the New Hampshire rule fear the possibility of "arbitrary popular justice by a lay jury," if juries are left without any guide in the determination of mental disease. GiuecK, op. cit. supra note 4, at 264. Critics also fear that, in the absence of any "independent court of experts," id. at 263, expert testimony, being partisan, is often based on "some wild theory which may help out the defendant's case." Id. at 250. Glusel:'s own position is that "there remains the process of constantly and intelligently bringing rules of guidance for juries into harmony with advancing scientific thought." Id. at $2 i s t$. Ray makes the same point in his letter of Mfarch 26,1869 , when he writes: "inasmuch as the courts insist on instructing the jury respecting the significance of certain scientific facts, they should do it in accordance with all the improvements which the batter opportunities of knowledge and the superior methods of study have introduced." 
such charges before he was a judge, naturally copied the same opinions in his Pleas of the Crown, as if they were settled law, when they were the erroneous opinions of physicians concerning matters of fact.

"The custom of courts charging juries as to matters of fact, ... arose from many circumstances peculiar to England in early times. First, in many cases in which the Crown took an interest, such as those affecting the rights of the Crown as opposed to the rights of the people, the judges, being then mere tools of the Crown, were used by the Crown to obtain verdicts favorable to the Crown. In that process the judges necessarily undertook to dictate to juries concerning the decision of questions of fact. Second, there was a vastly greater difference between the intelligence of the court and the jury, than there is now, and the tendency was for the learned and great judges to bestow their learning very liberally upon the ignorant and degraded jury, by way of instructions. Third, the use of experts as witnesses to give opinions upon scientific subjects was comparatively unknown. . . .

"The broad distinction between law and fact has never been drawn, nor attempted to be drawn, on the question of insanity, in any court whose decision has come to my knowledge. . . .

"The law does not declare every act of an insane person a nullity, because the law does not know that every act of an insane person is necessarily caused by his insanity. As I have said, the law is exhausted when it declares every product of mental disease a nullity. When judges learn that such is, and always was, the law, and confine themselves to it, the spirit and principle of law will be splendidly vindicated. Errors and mistakes of the great masters of our law, such as Coke, Hale, Blackstone, Mansfield, Marshall, Story, Taney, etc., on other subjects and branches of the law have been discovered and acknowledged, and courts have recognized the true principle of the law, however long it may have been misunderstood. And there is no peculiar reason for according the infallibility of any number of lawyers and judges in regard to the law of insanity. ..."

In Ray's reply of July 10,1868, while agreeing in principle "that the question for the jury to settle should be, simply, one of fact, with which the court has nothing to do," Ray "cannot see the propriety of denying that such tests and rules were the law,-erroneous, no doubt, but nevertheless the law."

"... In the days of Coke and Hale, it was supposed that insanity affected the mental powers in some cases much less gravely than it is supposed to do now. It became necessary for the court to inform the jury that, though they might find the prisoner insane, such insanity would not necessarily impair his perceptions of right and wrong, etc., etc., and consequently, not his legal responsibility. Without such instructions, they would have been all at sea. To have told the juries of those days that, if the act were the offspring of disease, the party must be acquitted, would not have simplified their task. To settle this point, it would have been necessary to answer the preliminary general question, what is disease? The information necessary to enlighten them respecting it, could have been derived 
only from experts or the court, for counsel were not in those days. The testimony of experts at that period, without counsel to give it pertinency, could not have imparted much light. Hence it became unavoidable that the court should tell the jury, what are the characters of mental disease; what the tests and rules by which its presence might be known. Such instructions became the law.

"I hare supposed that the law is just what the legislature chooses to make it, and if it declared that 'insanity' or 'unsoundness' or 'incompetence' should be followed by certain legal consequences, then would the court be going out of its province to instruct the jury as to the meaning of these terms?. . . The fault of lawyers, in my view of the subject, is, not that they have mistaken the law, but have failed to improve it by the help of modern enlightenment,-failed to malie it just what you propose. Under our modes of procedure, with the extreme freedom allowed to experts and counsel, the whole question had better be left to the jury in the shape you put it. ${ }^{22}$. . . It is simple, perfectly clear, and abundantly liberal. I am glad that it is to be formally presented, even though it be in the shape of a dissenting opinion."

In his letter of July 22,1868 , Judge Doe considers it just as much a duty for the law to correct its mistakes as for science to cast aside erroneous theories.

“. . . As to my dissenting opinion in Boardman v. Woodman, science was the same in the time of Hale that it is now. In his time the doctors made some mistakes about insanity, and courts adopted those mistakes. Those mistakes were not science and they were not law. The theory of the common law is that it is unchangealle, that lawyers and judges may make mistakes, as well as men of science, but that the law, being the perfection of reason, does not consist of such mistakes, any more than astronomy consists of the idea that the earth is flat and that the sun passes over it. It would be an anomaly in the law to hold that it takes cognisance of and follows only one of the sciences. If a jury were instructed that the laws of any other science were so and so, the verdict would be set aside, because questions of science are questions of fact for the jury, and whether delusion is or is not a test of insanity is purely a scientific question. It would be as erroneous in law to instruct a jury that delusion is not a test, as to instruct them that delusion is a test. How do we know that it is not? How do we know that you are not mistaken? The mistake of our predecessors was in taking judicial notice of contemporaneous medical opinion and adopting it as law. Now we have discovered their mistake, and it is our duty to correct it by declaring that to be a question of fact which they treated as a question of law. I am very

22. Critics of the New Hampshire rule argue that "mental disease" is such a vague and indeterminate term that to leave it to the jury is to leave the jury without any instruction. But, "the present practise, of giving the jury long and involved instructions on the subject of responsibility, in effect often comes to the same thing: the jury, unable to understand these long instructions, simply disregard them entirely, and settle the question of whether the defendant was "crazy' or not uron 'horse sense." "WEIIurs:;, Insanity as a Defense in Caminal Law $\$ 3$ n.43 (1933). 
urgent about this, because it is an impregnable position among lawyers when understood by them,-because it is the only just and humane view of the subject that they can understand and the only one they will ever be induced to accept. . . .

"I doubt whether a person who is not a lawyer can understand my position as a lawyer can understand it. There is a natural repugnance among us to the idea of making the law variable,- - depending upon the advancing and progressive opinion of men of science. Such an idea is at war with the fundamental theory of the law. Hale supposed that he was enumerating the tests established by nature, and that they were inflexible and eternal. If it had occurred to him that the progress of scientific men might show that these tests were not tests, he would not have announced them as law, although he might, according to the custom of his age and his country, have instructed juries as to his own opinion on all matters of fact including tests of insanity. ..."

In 1868, State $v$. Pike came to trial. The charge was murder and the defense was insanity by reason of dipsomania. Chief Justice Perley charged the jury in accordance with Doe's dissenting opinion in Boardman v. Woodman. ${ }^{23}$ Judge Doe's letter of December 21, 1868, takes on a note of triumph:

"It is certain that no such instructions were ever before given to a jury in England or America.

"...

"You will see that he [Chief Justice Perley] adopted my formula exactly.... In capital trials, two judges must be present. I was with the Chief Justice on Pike's trial."

Judge Doe's opinion in Pike repudiated the doctrine of the English judges. He pointed out that in the M'Naghten case "the testimony of the experts negatived the idea that knowledge of right and wrong is the test. And the admission of this evidence coupled with the rule given by the court to the jury that knowledge is the test, brought the law into conflict with itself. Either the experts testified on a question of law, or the court testified on a question of fact."24

"...

"The predicament is one which cannot be prolonged after it is realized. If the tests of insanity are matter of law, the practice of allowing experts to testify what they are, should be discontinued; if they are matters of fact, the judge should no longer testify without being sworn as a witness and showing himself qualified to testify as an expert." 25

Ray remarked in his letter of January 12, 1869:

"This rule indicates a great advance beyond the usual practice,-too great I fear to be very generally adopted even in your generation.

23. See note 15 supra. Boardman v. Woodman, 47 N.H. 120 (1868).

24. State v. Pike, 49 N.H. 399, 440 (1869).

25. Id. at 441 . 
However, we ought to be very thankful that it is likely to be adopted, shortly, in one state. I suppose it will finally be accepted everywhere, because I am sure it indicates the true spirit and genius of the law, and is in accordance with the temper and habits of our people."

Judge Doe enthusiastically outlined, in his letter of January 18, 1869, the strategy by which he hoped the legal profession could be induced to accept the New Hampshire rule:

"... The legal profession alone is to be convinced. And that profession is to be convinced only by the argument that our rule is the ancient, original theory of the common law,-older than Hale or Coke. State a legal proposition as new, and you waste your time arguing in support of it. In your profession it is not so, and it is not easy for a man of science, acknowledging and struggling for progress, to understand that the only common law progress which a lawyer will admit is the progress of reviving and restoring the primeval ideas and spirit and meaning of that law. ...

“... I do verily believe that to claim that your and my rule is a new one is to prevent its ever being adopted by the courts. If you could feel the force of this as I feel it, and if you could conscientiously advocate our principle not as a new medical discovery, to be now for the first time grafted upon the venerable stock of the common law, but as the venerable principle of the comnon law, freed from the ancient errors of undeveloped science which English judges gave to the jury as scientific truths, ... you could in my opinion give our principle an immense impetus, and bring the day of its general adoption much nearer than you now think possible, and sooner by an hundred years than by all other arguments put together. . . . If you ever write a criticism upon it, allow me to suggest that I utterly repudiate the idea of introducing a new principle into the common law by my dissenting opinion [in Bourdman $v$. Woodman], - that my strategic point is this: the principle contended for in that opinion is as old and venerable and fundamental and elementary as any principle of the common law. In hoc signo vinces. I dare say this seems to you disingenuous and Jesuitical, but it does not seem so to me."

In his reply of January 30,1869 , Ray wrote:

"... I should heartily endorse your opinion that the matter of insanity is a fact to be determined by the jury like any other fact. But it would be hardly becoming in me, a mere doctor, to charge your profession with having mistaken for so many generations a corruption of the rule for the pure, original rule itself, even if I felt, as I do not, competent for such a criticism. . . .

"More than 20 years ago ... I contended that, in adhering too closely to the letter of Coke and Hale, lawyers had completely quenched their spirit, for while they, Hale particularly, had evidently taken pains to ascertain the scientific facts respecting insanity and founded their rules upon those facts, their successsors had troubled themselves not at all to know of any fresh truth come to light, and, practically ignoring the spirit of inquiry evinced by their old masters, cared only to be led by their feeble light. ..." 
Judge Doe's next letter, March 23, 1869, contains a frank discussion of the prejudice of the legal profession against medical theory, present as well as past:

“. . Knowing the spirit and tendencies of my profession better than they can be understood by members of other professions, I am clearly of opinion that there is no prospect that American courts will adopt medical science as law. If they can be brought to leave questions of medical science to the jury as questions of fact (which they now do in regard to all other scientific questions), the long controversy between your profession and mine will be brought to an end, and you will be at liberty to convince the jury on subjects concerning which the courts have for a long time refused to be convinced, assuming as they have that upon the subject of insanity, the doctrine of medical science and the doctrine of the law were antagonistic. To remove this antagonism seems to me an immense gain. My faith is very strong, indeed, that it can be done. And my fear is very strong that it can be done within 100 years on no other basis than the principle which I have undertaken to establish. ... I was led to examinations which produced that opinion solely by a copy of the 3d edition of your Medical Jurisprudence of Insanity, which I bought when I began the practice of the law in 1854. Please accept the 47th New Hampshire Reports as a token of my appreciation of your labors in the cause of science and humanity. You reasoned this matter with the legal profession for a long time and against great discouragements. Since the contest began between your profession and mine on this subject, I think the arguments of no other physician or scientific man have produced any effect upon the Bench or Bar. The disagreement and variance promised to last forever. But I believe your triumph is near at hand. The triumph of the truth in this matter will be as exclusively your triumph as any victory can belong to one man.

"In Boardman v. Woodman, I should not have failed distinctly to acknowledge that the reform when accomplished will be the result of your efforts, had I not thought that by so doing I should have retarded the reform itself by repelling that very numerous class of lawyers and judges who can be easily stampeded by the cry of 'medical theory,' 'scientific innovations,' and 'doctors' notions.' . . . When people have an unfounded but ineradicable prejudice, by appealing to which the enemy will beat us, I think it is generally justifiable to carry it by storm and turn its guns upon the enemy. ... I thought that any reference to your views in Boardman v. Woodman would, in the minds of undiscriminating lawyers, detract from the force of the argument that no 'medical theory' is law, although I felt that by omitting to acknowledge the obligation which I felt towards you, I was doing you great injustice. . .."

In Ray's reply of March 26, 1869, he wrote:

"I wish I were fairly entitled to all the credit you give me. I claim little more than that of calling the attention of the two professions to the gross deficiencies of the 'law of insanity.' That I did this somewhat, I believe, for when my 1st edition was published in 1838 there was almost nothing on the subject in the English tongue." 
“. . Y You say, 'The point of my dissenting opinion is not what you wished. You thought we ought to follow the precedents and adopt as law the medical theories of our day, as Colie and Hale adopted those of their day.' If I have said this, and I dare say I have, but have forgotten it, I meant that inasmuch as the courts insist on instructing the jury respecting the significance of certain scientific facts, they should do it in accordance with all the improvements which the better opportunities of knowledge and the superior methods of study have introduced. But I gladly admit that, better than this, is the method you propose, of leaving every question of fact to the jury. I only fear that it is too philosophical and too revolutionary to be adopted speedily, though I do not doubt that it will finally prevail."

If Judge Doe, for reasons of strategy, refrained from making public acknowledgement of his debt to Isaac Ray, he similarly insisted that an article Ray was preparing for the Amcrican Laii Revicai on Doe's dissenting opinion in Boardman v. Woodman and on Chief Justice Perley's charge to the jury in State v. Pike must stress the role of Perley and minimize Due's. His letter of May 17, 1869, is strong on this point:

"... I think your article would be vastly more effective if it were transformed into a battery merely to support Perley's charge in Pike's case. In doing that, you will have the immense advantage of fighting in support of a great authority. ... You will have the protection of Perley's venerable and weighty name, which is greater in reality and reputation than that of any other man nuw on the Bench in New England. ... My great point, about which I am rery solicitous, is that you bring in Judge Perley immediately after the extracts from my opinion, and substitute his name for mine wherever it occurs afterwards in your article. ... It may occur to you to join my name with Perley's. Allow me to protest most decidedly against this. He is the only judge who has put the true doctrine into practice; he alone has actually done anything; it would be in bad taste to yoke him with a junior and subordinate who has only indulged in a dissenting opinion.... I think the legal mind of the country is ready to receive our doctrine, and needs only the authority of such a name and position as Perley's as responsible legal endorser, to accept it much sooner than you anticipate. ..."

In his letter of May 24, 1869, Ray reluctantly agreed:

“. . . I shall substitute Chief Justice Perley for Mr. Justice Doe, because you so earnestly wish it, but I shall do it under a lind of mental protest, for it looks very much like acting the play with the part of Hamlet left out, or, worse still, transferred to another character. ..."

When the New Hampshire rule was re-affirmed in State v. Jones, ${ }^{20}$ Judge Doe felt that the rule was at last firmly established. At the trial, Judge Doe delivered to the jury the same charge as Judge Perley had done in State $v$.

26. 50 N.H. 369 (1871). 
Pike. ${ }^{27}$ Judge Ladd, who wrote the opinion in Jones, reviewed all the tests of mental disease previously sanctioned by the courts. He concluded that "no formal rule can be applied in settling questions which have relation to liberty and life, merely because it will lessen the labor of the court or jury. ... Expressions of even the most eminent judges must not be mistaken for the enunciation of a universal principle of law, when it appears that they were used in charging the jury upon the facts arising in a particular case."28

The Doe-Ray correspondence contains several brief references to State $v$. Jones, which make it seem very probable that Judge Ladd, in preparing his opinion for the court, received considerable assistance from Judge Doe. Doe writes in his letter to Ray of January 26, 1872, for "the fullest and freest criticism" of his own opinion in State v. Pike, "so that I may be able to make any suggestions to Judge Ladd that may be useful." Isnac Ray's letter of November 17,1872, says he is exceedingly obliged for a package of the State v. Jones decision which.Judge Doe sent him. He adds that he anticipates "much good from the circulation of such views respecting the law of insanity." And with this letter, the correspondence ends.

\section{ConCLUSION}

But the controversy lingers on. It hinges on the point Ray raised with Doe that the law is concerned over defining legal responsibility regardless of the question of insanity, which may or may not disqualify from responsibility. It is a point which psychiatric expert testimony alone often cannot clarify to the satisfaction of the courts, and so today expert witnesses often fail to effect that closer harmony between science and the law for which Judge Doe and Dr. Ray had hoped. Indeed, these experts sometimes only make the already complex question of responsibility more confusing to the jury; for with present courtroom procedure, expert testimony being often partisan is apt to result in notorious "battles of the experts," each side more intent on partisanship than on the search for a common denominator of scientific truth. ${ }^{20}$

As to the New Hampshire rule itself, we can only conclude from the correspondence here presented that if it deals with matters too complicated for juries to decide unassisted, it nevertheless seeks to open the way for scientific progress in the jurisprudence of mental disease, and marks a step toward a true collaboration between science and the law in the spirit of Judge Doe and Dr. Ray.

27. See note 15 supra. State v. Jones, 50 N.HI. 369, 372-3 (1871).

28. Id. at 394 .

29. Various suggestions have been made to solve this problem. Zilboorg advocates that the psychiatric expert appear as a friend of the court, in a strictly neutral scientific and consulting capacity, instead of as a partisan witness for the defense or prosecution. Zilboorg, The Reciprocal Responsibilities of Law and Psychiatry in The Shingle, April, 1949, pp. 94-5. Or the role of psychiatrists, psychologists and sociologists may be limited to determining the type and duration of socio-penal treatment for the convicted. GuuEck, op. cit. supra note 4 , at 485 . 